\title{
A tribute to Vernon Ahmadjian (19 May 1930-13 March 2012)
}

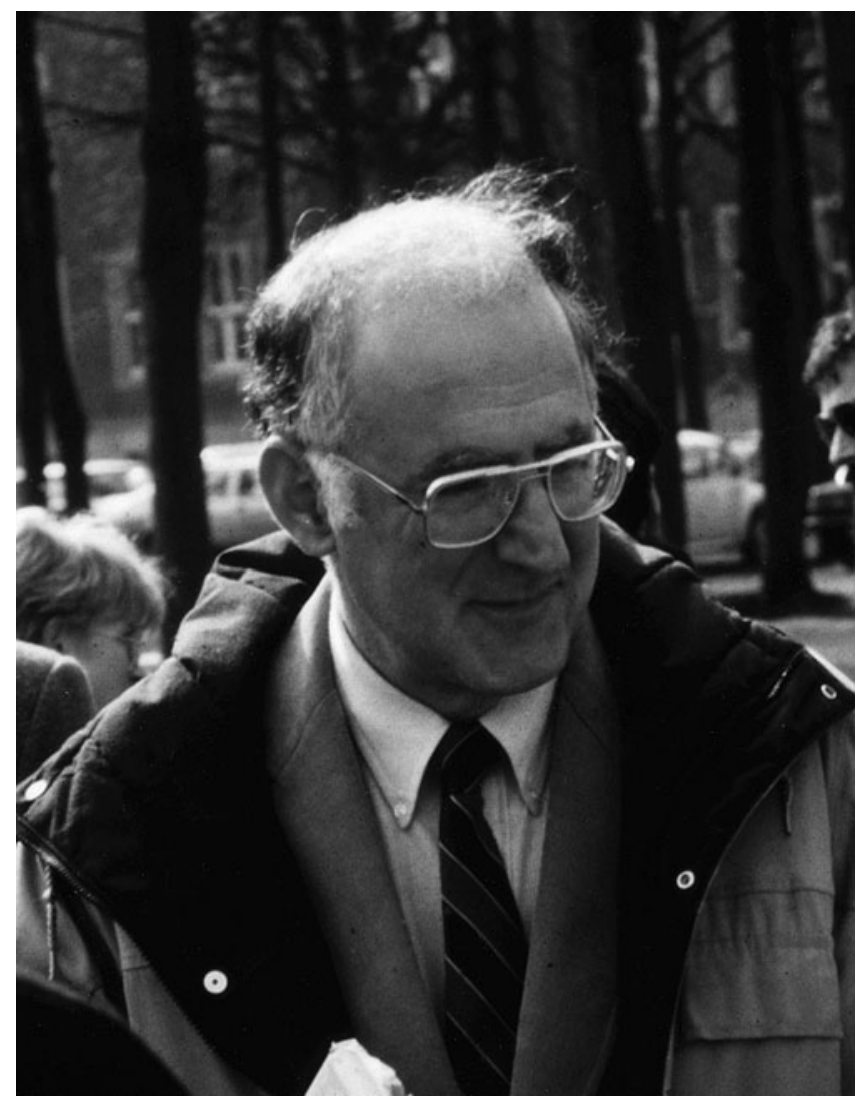

Dr Vernon Ahmadjian was the first person to develop consistently successful techniques for the laboratory synthesis of a variety of different lichen species from their isolated algal and fungal components. His research led to some penetrating discoveries concerning the factors that regulate the early development of lichens.

The son of Armenian immigrants to the USA, Ahmadjian was born and raised in Whitinsville, Massachusetts, and lived most of his life in Worcester, Massachusetts. After obtaining a B.A. in 1952 from Clark Univer- sity, Massachusetts, he served two years on military service with the US Army Combat Medical Corps in Korea. He returned to Clark University, obtaining an M.A. in 1956. A key event for him was meeting the lichenologist I. MacKenzie Lamb on a marine botany course in the summer of 1955. Lamb, then Director of the Farlow Herbarium at Harvard University, was taking the course in order to better curate and enlarge the Farlow collections. Their common keen interest in lichens led to Ahmadjian becoming Lamb's first Ph.D. student at Harvard. Lamb taught him 
Warén's micropipette technique for isolating lichen symbionts into laboratory culture, and introduced him to the unknowns of phycobiont taxonomy, on which Ahmadjian was also later to become one of the world's leading experts. Most importantly, Lamb passed on his own fascination with the experimental synthesis of lichens and the difficulties in achieving it to Ahmadjian, and this became one of his key lifelong interests. After obtaining his $\mathrm{Ph}$. D. at Harvard, he held brief posts at the University of Massachusetts and the University of California, Berkeley, before returning to Clark University where he spent most of the rest of his career researching lichens.

At that time, there were confusing reports on attempts at the laboratory synthesis of lichens. A decade or so after it was discovered in the 1860s that a lichen was composed of two separate organisms, the French biologist Gaston Bonnier reported the successful artificial synthesis of quite a number of lichens from their component algal and fungal symbionts; he used small stones or pieces of bark hung over water in a current of sterilised air. However, all subsequent attempts by various scientists to repeat these experiments failed, and Bonnier's work became the target of criticism and doubt. Thus, the Dutch lichenologist Quispel, in his classic 1943 review of the mutual relations between algae and fungi in lichens, wrote of Bonnier: “... he was the only investigator who pretended to have synthesised these lichens in pure culture ...". Quispel noted that all those scientists who had attempted such synthesis could at best only occasionally obtain the very beginnings of a thallus and no lichen was formed. The Swiss lichenologist E. A. Thomas imputed the failure of many attempts at synthesis to the use of the wrong substrata with overly high contents of water and/or of food substances. Thomas developed a technique involving the partial insertion of pieces of wood into $1 \%$ Knop agar inside flasks, and then inoculating those parts not submerged in the agar with pure cultures of fungus and alga. In only one of the 800 flasks used in these experiments was a successful complete synthesis observed. Quispel himself made numerous attempts at the laboratory synthesis of lichens: although the initial stages were often observed, these mostly died off or proceeded no further. $\mathrm{He}$ concluded that the methodological difficulties were so great that his objectives could only be realised to a very small degree.

This was the situation confronting Ahmadjian when his experimental work on lichen synthesis began in the late1950s. His success was due to his early appreciation of the importance for the initiation of a lichen synthesis that the level of available nutrients should be low (if symbionts are inoculated together on nutrient-rich agar they show no tendency to associate and grow quite independently). Synthesis progresses further if the cultures are subjected to slow, alternate periods of wetting and drying. Even better results are obtained if more natural substrata such as rock, wood or soil are used instead of agar. Ahmadjian described how the laboratory synthesis of Cladonia cristatella proceeded in the following stages. First, the hyphae encircle the symbiont - a non-specific stage since they would encircle in a similar manner a variety of non-symbiotic algae and even glass beads of a similar size. Secondly, the hyphae branch and continue to envelop symbionts to form soredia; the symbionts become surrounded by a gelatinous matrix of fungal origin and penetration of them by fungal haustoria commences. Thirdly, tissue differentiation by the fungus into cortex and medulla begins, with the algal symbionts confined to a distinct layer. Fourthly, in a few samples, synthesis proceeds as far as the formation of podetia and the initiation of fungal fruit bodies. Furthermore, transport of products of photosynthesis from algal to fungal symbionts commenced at about 12 weeks after their first contact.

Ahmadjian also made extensive studies of the phycobionts of lichens, especially the various species of Trebouxia and Pseudotrebouxia. Identical phycobionts were isolated from widely different lichen species, indicating that algae are not specific to particular mycobionts. In a study of the specificity of the fungus Cladonia cristatella for its Trebouxia symbionts, for example, he found that of nine Trebouxia spp. inoculated with the fungus, three were killed, but four pro- 
ceeded as far as thallus formation. However, no association was initiated with any of 12 Pseudotrebouxia spp. He considered the added problem that Trebouxia spp. are apparently rare in the free-living state. This raised the question of how lichens which do not form symbiotic propagules such as soredia but only have fungal fruit bodies reproduce in nature. With his co-workers, he observed zoosporogenesis in the Trebouxia gelatinosa symbiont of Parmelia (Xanthoparmelia) conspersa. These observations suggested that zoospores may be released within the thallus, escaping to form free-living microcolonies. These colonies could potentially then unite with spores from the same or genetically different mycobionts. Such natural resyntheses could be the cause for the observed heterogeneity characterizing the fungi of many lichen populations.

Ahmadjian's interests were not confined to the laboratory. He knew where the rare lichens grew in his county in Massachusetts, and campaigned to have these locations protected from development. In 1967 the National Science Foundation awarded him the Antarctic Medal for his work on lichens at the McMurdo station in Antarctica, and announced that an ice-covered, $2900 \mathrm{~m}$ peak in the Queen Alexandra Range of the Transantarctic had been named 'Ahmadjian Peak' in his honour. He was the first co-editor with Ernie Brodo (1967-1974) of the International Lichenological Newsletter, and in 1996, for his lifetime achievements in lichenology, particularly for his pioneering research, he was awarded the Acharius Medal. Nor were his botanical interests and achievements confined to lichenology: he was a champion for his local natural plant communities and a member of the Tower Hill Botanic Garden in Boylston, and in 1979 published a book on the Flowering Plants of Massachusetts. His students thoroughly enjoyed the field trips he led, for he was an excellent teacher.

Apart from publishing numerous research papers, Ahmadjian was the author of a highly significant textbook published in 1967, The Lichen Symbiosis (152 pages), a second edition appearing in 1993 (250 pages). In 1973, he co-edited with Mason Hale the highly influential book The Lichens (697 pages), and in 1986, together with Surindar Paracer, he published a more general text, Symbiosis. An Introduction to Biological Associations, a second edition appearing in 2000.

Sadly, opportunities to meet up with Vernon Ahmadjian have been all too few, but on those occasions when each of us did have the pleasure of his company they were both memorable and illuminating. Like us, those who have dealt with him over the years have deeply appreciated his thoughtfulness, courtesy and generosity, and can testify to his outstanding and unique contributions to our understanding of lichens.

\section{Selected Publications}

Over 90 lichenological and phycological papers and books are attributed to Vernon Ahmadjian, some of the more notable being:

Ahmadjian, V. (1958) A guide for the identification of algae occurring as lichen symbionts. Botaniska Notiser 111: 632-644.

Ahmadjian, V. (1959) A contribution toward lichen synthesis. Mycologia 51: 56-60.

Ahmadjian, V. (1960) The lichen association. Bryologist 63: $250-254$

Ahmadjian, V. (1961) Studies on lichenized fungi. Bryologist 64: 168-179.

Ahmadjian, V. (1962) Investigations on lichen synthesis. American fournal of Botany 49: 277-283.

Ahmadjian, V. (1966) Artificial reestablishment of the lichen Cladonia cristatella. Science 15: 199-201.

Ahmadjian, V. (1966) Cultural and physiological aspects of the lichen symbiosis. In Plant Biology Today. Advances and Challenges 2 nd ed. (W. A. Jensen \& L. G. Kavaljian, eds): 148-163. Belmont, California: Wadsworth Publishing.

Ahmadjian, V. (1966) Lichens. In Symbiosis, Volume 1. (S. M. Henry, ed.): 35-97. New York: Academic Press.

Ahmadjian, V. (1967) The Lichen Symbiosis. Waltham, Mass.: Blaisdell Publishing.

Ahmadjian, V. (1967) A guide to the algae occurring as lichen symbionts: isolation, culture, cultural physiology, and identification. Phycologia 6: 127-160.

Ahmadjian, V. (1970) The lichen symbiosis: its origin and evolution. In Evolutionary Biology, Volume 4. (T. Dobzhansky, M. K. Hecht \& W. C. Steere, eds): 163-184. New York. Appleton-Century Crofts.

Ahmadjian, V. (1980) Separation and artificial synthesis of lichens. In Cellular Interactions in Symbiosis and Parasitism (C. B. Cook, P. W. Pappas \& E. D. Rudolph, ed.): 3-29. Columbus: Ohio State University Press.

Ahmadjian, V. (1982) Algal/fungal symbioses. In Progress in Phycological Research. Volume 1 (F. E. Round \& D. J. Chapman, eds): 179-233. Amsterdam: Elsevier Biomedical Press. 
Ahmadjian, V. (1988) The lichen alga Trebouxia: does it occur free-living? Plant Systematics and Evolution 158: $243-247$.

Ahmadjian, V. (1989) Studies on the isolation and synthesis of bionts of the cyanolichen Peltigera canina (Peltigeraceae). Plant Systematics and Evolution 165: 29-38.

Ahmadjian, V. (1990) What have synthetic lichens told us about real lichens? Bibliotheca Lichenologica 38: 3-12.

Ahmadjian, V. (1993) The Lichen Symbiosis. 2nd edition. New York: John Wiley.

Ahmadjian, V. \& Hale, M. E. (ed.) (1973) The Lichens. New York: Academic Press.

Ahmadjian, V. \& Jacobs, J. B. (1981) Relationship between fungus and alga in the lichen Cladonia cristatella Tuck. Nature, London 289: 169-172.

Ahmadjian, V. \& Jacobs, J. B. (1982) Artificial re-establishment of lichens. III. Synthetic development of Usnea strigosa. Fournal of the Hattori Botanical Laboratory 52: 393-399.

Ahmadjian, V. \& Jacobs, J. B. (1983) Algal-fungal relationships in lichens: recognition, synthesis, and development. In Algal Symbiosis (L. J. Goff, ed.): 147-172. Cambridge: Cambridge University Press.
Ahmadjian, V. \& Jacobs, J. B. (1987) Studies on the development of synthetic lichens. Bibliotheca Lichenologica 25: 47-58.

Ahmadjian, V. \& Paracer, S. (1986) Symbiosis: an Introduction to Biological Associations. Hanover, N.H: University Press of New England.

Ahmadjian, V., Russell, L. A. \& Hildreth, K. C. (1980) Artificial reestablishment of lichens. I. Morphological interactions between the phycobionts of different lichens and the mycobionts of Cladonia cristatella and Lecanora chrysoleuca. Mycologia 72: 73-89.

Jacobs, J. B. \& Ahmadjian, V. (1969) The ultrastructure of lichens. I. A general survey. Fournal of Phycology 5: $227-240$.

Jacobs, J. B. \& Ahmadjian, V. (1971) The ultrastructure of lichens. II. Cladonia cristatella: the lichen and its isolated symbionts. Fournal of Phycology 7: 71-82.

Paracer, S. \& Ahmadjian, V. (2000) Symbiosis: an Introduction to Biological Associations. 2nd edition. Oxford: Oxford University Press.

David C. Smith and Mark R. D. Seaward 